\title{
Neurite Outgrowth by the Alternatively Spliced Region of Human Tenascin-C Is Mediated by Neuronal $\alpha 7 \beta 1$ Integrin
}

\author{
Mary Lynn T. Mercado, ${ }^{\star}$ Alam Nur-e-Kamal, ${ }^{\star}$ Hsing-Yin Liu, ${ }^{\star}$ Stephane R. Gross, ${ }^{\star}$ Reza Movahed, and Sally Meiners \\ Department of Pharmacology, University of Medicine and Dentistry of New Jersey, Robert Wood Johnson Medical School, Piscataway, New Jersey 08854
}

The region of tenascin-C containing only alternately spliced fibronectin type-III repeat $\mathrm{D}(\mathrm{fnD})$ increases neurite outgrowth by itself and also as part of tenascin-C. We previously localized the active site within $\mathrm{fnD}$ to an eight amino acid sequence unique to tenascin-C, VFDNFVLK, and showed that the amino acids FD and FV are required for activity. The purpose of this study was to identify the neuronal receptor that interacts with VFDNFVLK and to investigate the hypothesis that FD and FV are important for receptor binding. Functionblocking antibodies against both $\alpha 7$ and $\beta 1$ integrin subunits were found to abolish VFDNFVLK-mediated process extension from cerebellar granule neurons. VFDNFVLK but not its mutant, VSPNGSLK, induced clustering of neuronal $\beta 1$ integrin immunoreactivity. This strongly implicates FD and FV as important structural elements for receptor activation. Moreover, biochemical experiments revealed an association of the $\alpha 7 \beta 1$ integrin with tenascin-C peptides containing the VFDNFVLK sequence but not with peptides with alterations in FD and/or FV. These findings are the first to provide evidence that the $\alpha 7 \beta 1$ integrin mediates a response to tenascin-C and the first to demonstrate a functional role for the $\alpha 7 \beta 1$ integrin receptor in CNS neurons.

Key words: tenascin-C; FN-III repeat; alternatively spliced region; synthetic peptide; site-directed modifications; neurite outgrowth; $\alpha 7 \beta 1$ integrin

\section{Introduction}

The extracellular matrix molecule tenascin-C exists as a family of alternatively spliced variants with major actions to modulate neuronal growth and migration (Bronner-Fraser, 1988; Gates et al., 1996). Tenascin-C splice variants differ only in their number of fibronectin type III (FN-III) repeats: all variants of human tenascin-C have nine universal FN-III repeats, whereas the largest splice variant has a series of alternatively spliced FN-III repeats (fnA-D) that are missing in the smallest (see Fig. $1 A$ ). Periods of increased axonal growth in the developing CNS have been closely correlated with expression of large but not small tenascin-C (Crossin et al., 1989; Tucker, 1993), suggesting that fnA-D might stimulate neuronal growth during embryogenesis.

We and others (Gotz et al., 1996; Meiners and Geller, 1997) have implicated alternatively spliced FN-III repeat D (fnD) as providing the stimulus for neuronal process extension. We demonstrated previously that a short linear amino acid sequence in $\mathrm{fnD}$ derived from human tenascin-C, VFDNFVLK, is necessary and sufficient for outgrowth promotion from cerebellar granule neurons. Furthermore, FD and FV are critical for activity (Meiners et al., 2001). The purpose of the current study was to identify

\footnotetext{
Received 0ct. 3, 2003; accepted 0ct. 16, 2003.

This work was supported by National Institutes of Health Grant R01 NS40394 and Paralyzed Veterans of America Spinal Cord Research Foundation Grant 2148 (S.M.). We thank Dr. Harold Erickson for helpful discussions and for assistance with Figure $1 B$ and Drs. Bonnie Firestein and Herbert Geller for helpful discussions.

${ }^{*}$ M.L.T.M., A.N.-E.-K., H.-Y.L., and S.R.G. contributed equally to this work.

Correspondence should be addressed to Dr. Sally Meiners, Department of Pharmacology, University of Medicine and Dentistry of New Jersey, Robert Wood Johnson Medical School, 675 Hoes Lane, Piscataway, NJ 08854. E-mail: meiners@umdnj.edu.

DOI:10.1523/JNEUROSCI.4519-03.2004

Copyright $\odot 2004$ Society for Neuroscience $\quad$ 0270-6474/04/240238-10\$15.00/0
}

the neuronal receptor that interacts with VFDNFVLK and to investigate the hypothesis that FD and FV are required for receptor binding.

A comparison of VFDNFVLK in $\mathrm{fnD}$ and the corresponding sequence EIDGIELT in universal FN-III repeat 3 (fn3) implicates a $\beta 1$ integrin as a candidate receptor for VFDNFVLK. The structure of fn3 has been reported previously (Leahy et al., 1992), and EIDGIELT includes portions of an exposed loop and adjacent $\beta$ strand (see Fig. $1 B$ ). D in the exposed loop and $\mathrm{E}$ in the adjacent $\beta$ strand are required for binding to the integrin $\alpha 9 \beta 1$ (Yokosaki et al., 1998). By analogy, it is likely that FD found in VFDNFVLK is localized on an exposed loop in $\mathrm{fnD}$ for an interaction with neurons, whereas FV is likely localized on a semi-buried $\beta$ strand, in which it may lend conformational stability rather than binding directly to neurons. However, it is unlikely that VFDNFVLK binds to the $\alpha 9 \beta 1$ integrin, because $\alpha 9 \beta 1$ has not been detected in brain (Huang et al., 2000).

We therefore explored the hypothesis that VFDNFVLK binds to the $\alpha 7 \beta 1$ integrin, better known as a laminin- 1 receptor involved in neuromuscular (Burkin et al., 1998) and myotendinous (Crawley et al., 1997) junctions. Tenascin-C is enriched at neuromuscular and myotendinous junctions (Chiquet and Fambrough, 1984; Cifuentes-Diaz et al., 2002), colocalizing it with $\alpha 7 \beta 1$. Moreover, mRNA transcripts for $\alpha 7$ integrin have been found in many of the same brain regions as tenascin- $\mathrm{C}$, including the cerebellum (Pinkstaff et al., 1999). We now show that function blocking antibodies against both $\alpha 7$ and $\beta 1$ integrin subunits abolished neurite outgrowth promotion by VFDNFVLK. Ligand binding assays revealed an association of $\alpha 7 \beta 1$ with tenascin-C peptides containing the VFDNFVLK sequence but not peptides with alterations in FD and/or FV. These results in- 

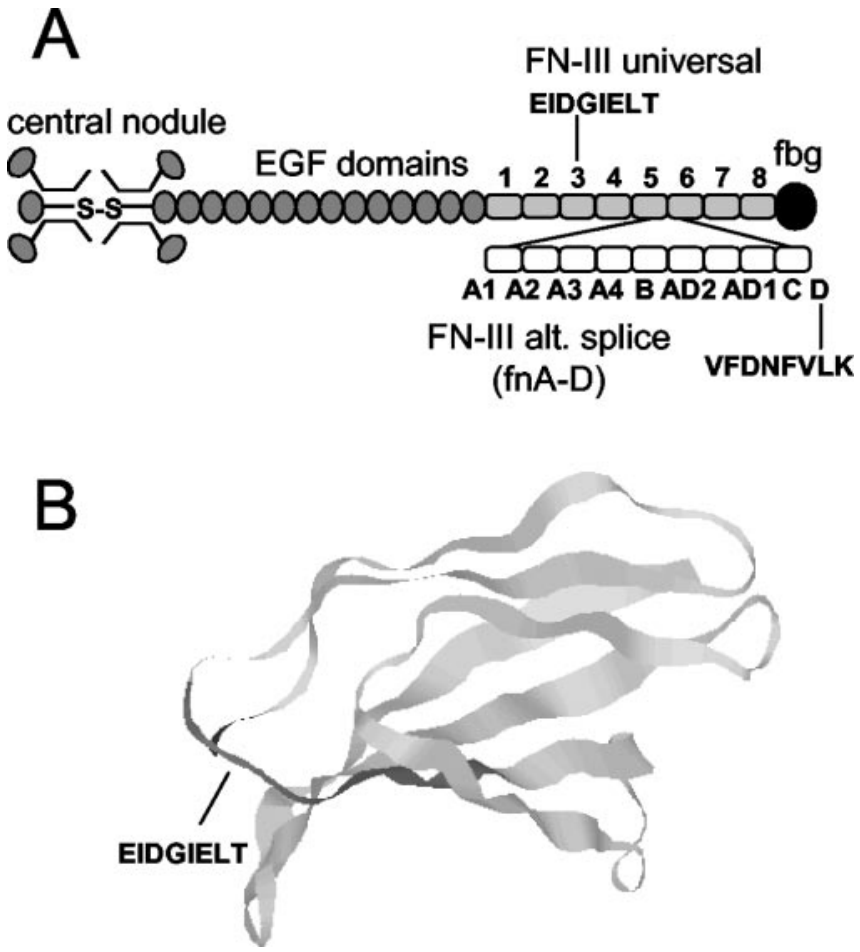

Figure 1. Structure of human tenascin-C. $A$, Organization of the tenascin- $C$ molecule. This diagram is adapted from Aukhil et al. (1993). The $\mathrm{N}$ termini of three arms are joined to form a trimer, and two trimers are connected via a disulfide bond (S-S) to form a hexamer. Each arm consists of 14 domains with homology to epidermal growth factor (EGF), 8-17 FN-III repeats depending on alternative RNA splicing, and a single fibrinogen (fbg) domain. The universal FN-III repeats (fn1-5 and fn6-8) are present in all tenascin-C splice variants. The largest tenascin-C splice variant contains nine alternatively spliced FN-III repeats (designated A1, A2, $A 3, A 4, B, A D 1, A D 2, C$, and $D$, or fnA-D), which are missing in the shortest splice variant. $B$, Crystal structure of universal tenascin-C FN-III domain 3 (fn3). This structure is adapted from Leahy et al. (1992) and consists of six exposed loops and seven $\beta$ strands. The $\alpha 9 \beta 1$ integrin recognition sequence EIDGIELT, which corresponds to the neurite outgrowth-promoting sequence VFDNFVLK in fnD, is highlighted and includes portions of an exposed loop and adjacent $\beta$ strand.

dicate that the $\alpha 7 \beta 1$ integrin mediates a response to tenascin- $\mathrm{C}$ and provide the first functional data on the role of $\alpha 7 \beta 1$ in CNS neurons.

\section{Materials and Methods}

Proteins and antibodies. Recombinant wild-type and mutant fnD proteins corresponding to alternatively spliced FN-III repeat D of human tenascin- $C$ were prepared as described previously (Meiners et al., 2001) (Fig. 1). The mutant was created so that amino acid sequence FDNFV of $\mathrm{fnD}$ was replaced by SPNGS. Synthetic peptides derived from the $\mathrm{fnD}$ repeat of human tenascin-C were prepared by BioSynthesis (Lewisville, TX). Peptides were characterized by the company using both mass spectral analysis and HPLC tracing. Transfected baby hamster kidney cells were a gift from Dr. Harold Erickson (Department of Cell Biology, Duke University Medical Center, Durham, NC). Splice variants of human tenascin-C were produced in the transfected cells (Aukhil et al., 1993). Native large tenascin- $C$ was purified from culture supernatants of these cells by gelatin-Sepharose and hydroxyapatite chromatography (Aukhil et al., 1993), followed by electroelution from nondenaturing gels (S. Meiners, unpublished data). Purified mouse Engelbreth-Holm-Swarm sarcoma laminin-1 and human serum fibronectin were from Invitrogen (Rockville, MD).

Function-blocking hamster monoclonal antibodies against rat $\beta 1$ (Ha2/5), rat $\alpha 1$ (Ha31/8), and rat $\alpha 2(\mathrm{Ha} 1 / 29)$ integrin chains were purchased from PharMingen (San Diego, CA). Function-blocking hamster monoclonal antibody against mouse $\alpha 6(\mathrm{GoH} 3)$ integrin chain was purchased from Immunotech (Marseille, France). Function-blocking mouse monoclonal antibody against rat $\alpha 3$ integrin chain (Ralph 3.1) was developed by Dr. Louis Reichardt and obtained from the Developmental Studies Hybridoma Bank [created under the auspices of the National Institute of Child Health and Human Development and maintained by the University of Iowa, (Iowa City, IA)]. Function-blocking mouse monoclonal $\mathrm{O} 26$ antibody against rat $\alpha 7$ integrin chain was kindly provided by Dr. Stephen Kaufman (Department of Cell and Structural Biology, University of Illinois, Urbana, IL). Affinity-purified rabbit polyclonal antibodies against the $\mathrm{A}$ and $\mathrm{B}$ cytoplasmic variants of mouse $\alpha 7$ integrin chain were kindly provided by Dr. Eva Engvall (The Burnham Institute, La Jolla, CA). Rabbit polyclonal antibody against human $\beta 1$ integrin chain was purchased from Santa Cruz Biotechnology (Santa Cruz, CA). Rabbit polyclonal antibody against human full-length tenascin-C was kindly provided by Dr. Harold Erickson.

Neuronal culture. Cerebellar granule neuronal cultures were prepared from postnatal day 8 (P8) rat or P6 mouse pups as described previously (Meiners et al., 2001). The pellet containing cerebellar granule neurons was resuspended in neurobasal medium (NBM) (Invitrogen) supplemented with B27 (Invitrogen) plus $25 \mathrm{~mm} \mathrm{KCl}$ plus 1\% penicillin-streptomycin (NBM/B27/KCl) and used for neurite outgrowth assays.

Neurite outgrowth assay. Neurite outgrowth, in response to $\mathrm{fnD}$ and its neurite outgrowth-promoting peptide VFDNFVLK, as well as the extracellular matrix molecules tenascin- $\mathrm{C}$, laminin-1, and fibronectin, was evaluated as follows. Poly-L-lysine (PLL)-coated glass coverslips in 24well trays were incubated with protein or peptide solutions $(20 \mu \mathrm{g} / \mathrm{ml}$ in HBSS) overnight at $37^{\circ} \mathrm{C}$. Excess solution was rinsed away with HBSS. Substrate coating efficiencies were determined by incubating coverslips overnight with proteins or peptides conjugated to $N$-hydroxysuccinimidefluorescein (Pierce, Rockford, IL). The fluorescence of proteins or peptides bound to PLL-coated glass was then assessed as we described previously (Meiners et al., 1999, 2001).

Cerebellar granule neurons were plated onto the coverslips containing bound proteins or peptides at a density of 60,000 neurons per well. The neurons were allowed to extend neurites for $24 \mathrm{hr}$ in NBM/B27/KCl. To study the effect of soluble peptide, VFDNFVLK was first bound to the coverslips as described above; cerebellar granule neurons were then cultured for $24 \mathrm{hr}$ on the coverslips in medium containing an excess of soluble peptide (300 nm). The extent of neurite outgrowth was then determined using carboxyfluorescein diacetate (CFDA) labeling (Petroski and Geller, 1994). CFDA (Sigma, St. Louis, MO) intensely stains the soma and all processes of cultured, living neurons. Images of the cultures were captured using a Macintosh Quadra 700 (Apple Computers, Cupertino, CA) and analyzed with the NIH Image software. A sample of 50-75 neurons with well defined processes greater than one cell soma was considered for each condition. Cultures were scored by individuals blind to the treatment groups. The length of each primary process and its branches was measured for each neuron, and the total neurite length was calculated as the sum of the lengths of individual neurites.

Antibody blocking experiments. The hypothesis that $\mathrm{fnD}$ and the VFDNFVLK peptide facilitate neuronal process extension via a $\beta 1$ integrin neuronal receptor was tested in neurite outgrowth experiments using a function-blocking monoclonal antibody against rat $\beta 1$ integrin chain. FnD or VFDNFVLK $(20 \mu \mathrm{g} / \mathrm{ml})$ were bound to PLL-coated glass coverslips overnight at $37^{\circ} \mathrm{C}$, and excess solution was then washed away. Rat cerebellar granule neurons were plated onto the coverslips in NBM/B27/ $\mathrm{KCl}$ and allowed to adhere for $1 \mathrm{hr}$. Hamster anti-rat $\beta 1$ integrin chain $(0.5-100 \mu \mathrm{g} / \mathrm{ml})$ was added to the cultures, and neurons were allowed to extend processes for another $23 \mathrm{hr}$. In some cases, excess soluble VFDNFVLK was added immediately after plating the neurons, and $\beta 1$ antibody was added $1 \mathrm{hr}$ later. Neurons were then allowed to extend processes in the presence of soluble peptide and $\beta 1$ antibody for $23 \mathrm{hr}$.

To explore the identity of the $\alpha$ integrin chain partner for $\beta 1$, we also tested a panel of antibodies against $\alpha$ integrin subunits $(0.5-100 \mu \mathrm{g} / \mathrm{ml})$ for interference with neurite promotion by VFDNFVLK. This panel included antibodies against rat $\alpha 1, \alpha 2, \alpha 3$, and $\alpha 7$ integrin chains, as well as an antibody against mouse $\alpha 6$ integrin chain. The antibodies against rat 
and mouse integrins were tested in assays using rat and mouse neurons, respectively.

Immunocytochemistry for $\beta 1$ integrin chain. Potential clustering of a $\beta 1$ integrin neuronal receptor in response to VFDNFVLK and/or VSPNGSLK was investigated using immunocytochemical techniques. Rat cerebellar granule neurons were plated onto peptide-coated coverslips at a density of 60,000 neurons per well and cultured for $24 \mathrm{hr}$ in $\mathrm{NBM} / \mathrm{B} 27 / \mathrm{KCl}$. Coverslips were fixed with acetic acid-ethanol (5\%-95\%) for $10 \mathrm{~min}$ at $-20^{\circ} \mathrm{C}$ and incubated with monoclonal hamster antibody against rat $\beta 1$ integrin chain $(10 \mu \mathrm{g} / \mathrm{ml})$, followed by a fluorescein-conjugated goat anti-hamster secondary antibody (PharMingen). All antibody dilutions were made in PBS containing 10\% FCS. The control for nonspecific binding of the secondary antibody was performed by omitting the primary antibody in parallel cultures. Images of the cultures were captured using a Macintosh Quadra 700.

Western blot analysis of $\alpha 7$ integrin chain in cerebellar granule neurons. Expression of $\alpha 7$ integrin chain in rat cerebellar granule neurons was examined using Western blotting techniques. Nitrocellulose paper from Bio-Rad (Hercules, CA) was used for this and subsequent experiments. Neurons were homogenized on ice in Laemmli sample buffer (Laemmli, 1970). The homogenate ( $25 \mu \mathrm{g}$ ) was subjected to SDS-PAGE ( $8 \%$ ) (Laemmli, 1970) under nonreducing conditions and Western blotting (Towbin et al., 1979) with monoclonal O26 antibody, which cross-reacts with all splice variants of rat $\alpha 7$ integrin, both extracellular and cytoplasmic (Crawley et al., 1997), or polyclonal $\alpha 7 \mathrm{~A}$ or $\alpha 7 \mathrm{~B}$ antibodies, which specifically cross-react with variants containing either the A or B cytoplasmic tail (Vachon et al., 1997). Immunoreactive bands were visualized using horseradish peroxidase-conjugated secondary antibodies and the enhanced chemiluminescence method (ECL system; Amersham Biosciences, Arlington Heights, IL).

Amplification of $\alpha 7$ integrin isoforms by reverse transcription-PCR. To further explore neuronal expression of extracellular and cytoplasmic $\alpha 7$ integrin splice variant(s), PCR was performed as described previously (Ziober et al., 2002) on reverse transcribed total RNA isolated from rat cerebellar granule neurons. Total RNA was isolated using the RNeasy mini kit according to the instructions of the manufacturer Qiagen, Santa Clarita, CA). Reverse transcription (RT) of total RNA was done using 10 $\mu \mathrm{g}$ of RNA, random primers, and reverse transcriptase according to the instructions of the manufacturer (Pharmacia, Piscataway, NJ). For each set of PCR reactions, negative controls, which lacked reverse transcriptase or total RNA, were always included.

Primers used in the amplification of the X1 extracellular variant of the $\alpha 7$ integrin subunit were $\mathrm{X} 1 / \mathrm{X} 2$ antisense primer 5 '-CTATCCTTGCGCAGAATGAC-3' and X1 sense primer 5'-GCCAGGGTGGAGCTCTG-3'; primers for amplification of the $\mathrm{X} 2$ extracellular variant were $\mathrm{X} 1 / \mathrm{X} 2$ antisense primer $5^{\prime}$-CTATCCTTGCGCAGAATGAC-3' and X2 sense primer $5^{\prime}$-GTGACCAACATTGATAGCTC-3'; primers used in the amplification of the A cytoplasmic variant were $\mathrm{AB}$ antisense primer 5'-CACCGGATGTCCATCAGGAC-3' and either AB sense primer $5^{\prime}$-GCTGCTCAGAGATGCATCC- $3^{\prime}$ or A sense primer $5^{\prime}$-CGGAACAGTCCAAGCTCCTCA-3'; primers used in the amplification of the $B$ cytoplasmic variant were $A B$ antisense primer 5'-CACCGGATGTCCATCAGGAC-3' and AB sense primer $5^{\prime}$-GCTGCTCAGAGATGCATCC-3'. (The AB antisense primer used in combination with the $A B$ sense primer amplifies both $A$ and $B$ variants, whereas the $A$ sense primer is specific for $A$.) These primers are based on the sequence of mouse $\alpha 7$ integrin; X1/X2 antisense, X1 sense, X2 sense, $\mathrm{AB}$ antisense, and $\mathrm{AB}$ sense were used previously to amplify $\alpha 7$ integrin PCR products from reverse-transcribed total RNA isolated from both rat and mouse tissues (Ziober et al., 2002).

Preparation of neuronal cell extracts. Cerebellar granule neuronal extracts were prepared using methods adapted from published protocols (Kramer et al., 1991; Gu et al., 1994). Cerebellar granule neurons were plated in $35 \mathrm{~mm}$ PLL-coated tissue culture dishes in NBM/B27/KCl at a density of $2 \times 10^{6}$ cells per dish. After $24 \mathrm{hr}$ in culture, neurons were washed three times with cold PBS and scraped on ice into PBS (100 $\mu$ l per plate of cells) containing $1 \%$ protease inhibitor mix for mammalian cells (PBS+; Sigma). The extracts were pooled and pelleted by centrifugation at 20,000 $\times \mathrm{g}$ for $30 \mathrm{~min}$. The pellet was then resuspended in buffer $\mathrm{A}$ (200 mm $n$-octyl- $\beta$-D-glucopyranoside, $0.05 \%$ Triton X-100, $1 \%$ pro- tease inhibitor mix, and $100 \mathrm{~mm}$ Tris- $\mathrm{HCl}, \mathrm{pH}$ 7.4) (100 $\mu$ l per plate of cells) and incubated on a rotary shaker for $1 \mathrm{hr}$ at $4^{\circ} \mathrm{C}$. The mixture was centrifuged at $20,000 \times g$, and the supernatant was adjusted to $2 \mathrm{~mm}$ $\mathrm{CaCl}_{2}$ and used for tensacin-C peptide affinity chromatography.

Tenascin-C peptide affinity chromatography. To establish binding of the $\alpha 7 \beta 1$ integrin to the neurite outgrowth-promoting motif in the $\mathrm{fnD}$ repeat of tenascin- $\mathrm{C}$, ligand binding experiments using affinity chromatography were performed with D5 peptide (Meiners et al., 2001). D5 (complete sequence, VFDNFVLKIRDTKKQ), which contains the VFDNFVLK sequence and also promotes neurite outgrowth via VFDNFVLK (Meiners et al., 2001), was used in these experiments instead of VFDNFVLK itself because it is more hydrophilic and readily soluble. This allowed us to use a higher concentration of peptide $(100 \mu \mathrm{g} / \mathrm{ml}$, as opposed to the $20 \mu \mathrm{g} / \mathrm{ml}$ VFDNFVLK used in the neurite outgrowth experiments described above) in the affinity chromatography experiments.

D5 peptide was coupled to cyanogen bromide-activated Sepharose (Amersham Biosciences, Piscataway, NJ) at $100 \mu \mathrm{g} /$ protein/ml beads according to the instructions of the manufacturer. To evaluate the contribution of the conserved residues FD and FV to integrin binding, D5 peptides with amino acid substitutions in FD and/or FV were also conjugated to beads. The altered D5 peptides included D5 mutant 1

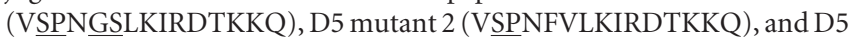
mutant 3 (VFDNGSLKIRDTKKQ). Unreacted sites on the beads were blocked with $1 \mathrm{~m}$ ethanolamine- $\mathrm{HCl}, \mathrm{pH}$ 8.0. Uncoupled but blocked Sepharose served as a negative control. Peptide-conjugated and control Sepharose beads were equilibrated with $10 \mathrm{ml}$ of buffer A ( $50 \mathrm{~mm} n$-octyl$\beta$-D-glucopyranoside, $50 \mathrm{~mm}$ Tris-HCl, $\mathrm{pH} 7.4$, and $2 \mathrm{~mm} \mathrm{CaCl}_{2}$ ). Each type of Sepharose $(250 \mu \mathrm{l})$ was then added to $500 \mu \mathrm{l}$ of cerebellar granule neuronal extract and incubated on a rotary shaker for $16 \mathrm{hr}$ at $4^{\circ} \mathrm{C}$. Sepharose-cerebellar protein complexes were pelleted at low speed $(3000 \times g)$ and washed six times with buffer A and then two times with buffer A containing $50 \mathrm{~mm} \mathrm{NaCl}$. The beads were eluted three times with $200 \mu \mathrm{l}$ washes of $10 \mathrm{~mm}$ EDTA in buffer A (without $\mathrm{CaCl}_{2}$ ). The EDTA eluates were immediately adjusted to $20 \mathrm{~mm} \mathrm{CaCl}_{2}$ and dialyzed overnight at $4^{\circ} \mathrm{C}$ against buffer $\mathrm{B}(0.1 \%$ SDS, $10 \mathrm{~mm}$ Tris- $\mathrm{HCl}, 0.02 \%$ protease inhibitor, and $2 \mathrm{mM} \mathrm{CaCl}_{2}, \mathrm{pH}$ 7.2). The presence of $\alpha 7 \beta 1$ integrin in the eluates was tested by Western blotting with monoclonal O26 antibody against $\alpha 7$ integrin chain and polyclonal $\beta 1$ integrin chain antibody.

\section{Results}

\section{Neurite outgrowth promotion by FnD and VFDNFVLK is mediated by a neuronal $\beta 1$ integrin}

We first investigated whether $\mathrm{fnD}$ and its neurite-outgrowth promoting sequence VFDNFVLK interact with a neuronal $\beta 1$ integrin to facilitate process extension. PLL-coated glass coverslips were incubated with HBS alone (control) or with fnD or VFDNFVLK peptide $(20 \mu \mathrm{g} / \mathrm{ml})$ overnight at $37^{\circ} \mathrm{C}$. Substrate coating efficiencies were $4.3 \pm 0.9 \mathrm{pmol} / \mathrm{cm}^{2}$ for VFDNFVLK and $7.1 \pm$ $0.5 \mathrm{pmol} / \mathrm{cm}^{2}$ for $\mathrm{fnD}$ under these conditions. Rat cerebellar granule neurons were plated onto the coverslips and allowed to extend neurites for $24 \mathrm{hr}$. In some conditions, a hamster monoclonal function-blocking antibody against rat $\beta 1$ integrin chain $(0.5-100 \mu \mathrm{g} / \mathrm{ml})$ was added $1 \mathrm{hr}$ after plating neurons and then included during the remaining $23 \mathrm{hr}$ of the experiment. [Adding the $\beta 1$ antibody at the same time as plating the neurons impaired neuronal adhesion to $\mathrm{fnD}$ and VFDNFVLK, whereas adding antibody $1 \mathrm{hr}$ later had no obvious effect on adhesion (data not shown).] The extent of neurite outgrowth was then assessed.

Distributions of total neurite length for neurons cultured on each substrate are presented in Figure $2 A$. FnD and VFDNFVLK both enhanced neurite growth compared with the PLL control, as we showed previously (Meiners et al., 2001). The $\beta 1$ antibody did not alter the distribution of total neurite lengths on PLL but eliminated the enhancement of neurite outgrowth by $\mathrm{fnD}$ and VFDNFVLK. Hence, the $\beta 1$ integrin antibody specifically blocked outgrowth promoted beyond the control level by fnD 
A

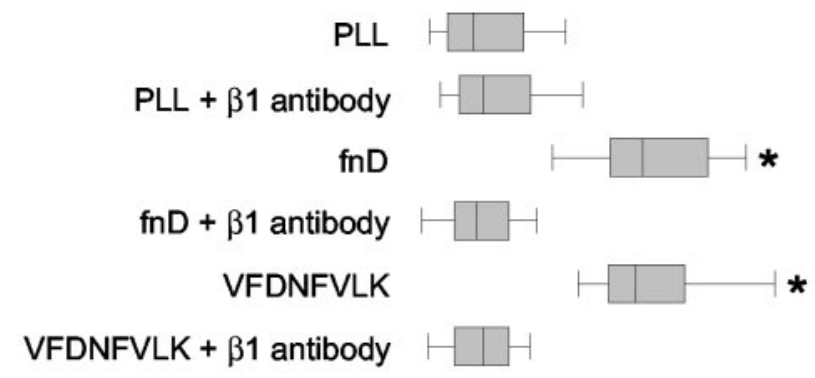

$\begin{array}{llllllll}0 & 20 & 40 & 60 & 80 & 100 & 120 & 140\end{array}$

B

Total neurite length $(\mu \mathrm{m})$

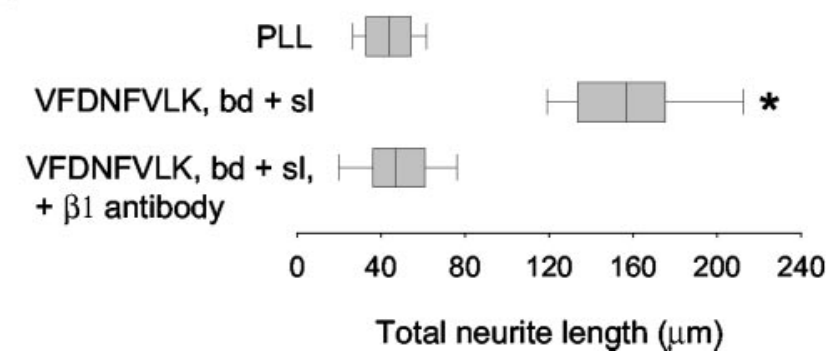

Figure 2. $\quad A \beta 1$ integrin neuronal receptor is implicated in promotion of neurite outgrowth by fnD and VFDNFVLK. A, Rat cerebellar granule neurons were cultured for $24 \mathrm{hr}$ on PLL-coated glass coverslips in the presence of bound fnD or VFDNFVLK and a function-blocking antibody against $\beta 1$ integrin subunit $(10 \mu \mathrm{g} / \mathrm{mll})$. Distributions of total neurite length are presented as a box-and-whisker plot. One representative experiment of four is shown. Boxes enclose 25th and 75th percentiles of each distribution and are bisected by the median; whiskers indicate 5 th and 95th percentiles. FnD and VFDNFVLK significantly enhanced outgrowth compared with the PLL control ( ${ }^{*} p<0.05$; Kolmogorov-Smirnov test). The $\beta 1$ integrin antibody did not alter neurite outgrowth on PLL but completely blocked outgrowth promotion by fnD and VFDNFVLK. $B$, Neurons were cultured for $24 \mathrm{hr}$ on PLL-coated coverslips in the presence of bound plus excess soluble (bd + sl) VFDVFVLK and $\beta 1$ integrin antibody. One representative experiment of three is shown. Outgrowth values were higher than those observed in $A$ for neurons cultured on bound peptide alone and reduced to control values in the presence of $\beta 1$ antibody.

and VFDNFVLK but did not alter the basal level of growth on the control substrate. Interactions of matrix molecules with integrins have been primarily attributed to sites that have an Arg-Gly-Asp (RGD) sequence (Ruoslahti, 1996). Our data suggest that a $\beta 1$ integrin mediates promotion of neurite outgrowth by VFDNFVLK in $\mathrm{fnD}$, which is a non-RGD sequence, much as a $\beta 1$ integrin mediates cell attachment to the corresponding non-RGD sequence (EIDGIELT) in fn3 (Yokosaki et al., 1998).

Inhibition of outgrowth on fnD and VFDNFVLK was dose dependent, with the maximal effect observed at 5-10 $\mu \mathrm{g} / \mathrm{ml}$ antibody (data not shown); the illustrated results (Fig. 2A) were obtained using $10 \mu \mathrm{g} / \mathrm{ml}$ antibody. No inhibition of outgrowth was observed when an anti-hamster IgM isotype control antibody was used instead of the $\beta 1$ integrin antibody (data not shown). Identical results were obtained using D5 (VFDNFVLKIRDTKKQ), a 15 amino acid peptide derived from fnD that contains the VFDNFVLK sequence and promotes neurite outgrowth to the same extent as VFDNFVLK (Meiners et al., 2001) (data not shown). The fact that outgrowth on the tenascin-Cderived molecules in the presence of the $\beta 1$ antibody was indistinguishable from control suggests that negligible process extension occurred during the first hour of the experiment, before the addition of the antibody.
We showed that VFDNFVLK promotes outgrowth when bound as well as when soluble (Meiners et al., 2001). Therefore, the ability of the $\beta 1$ antibody to block the effects of soluble VFDNFVLK was also evaluated. Peptide was first bound to coverslips, and excess peptide in solution (300 nM) was added. Neurons were then plated onto the coverslips and cultured in the presence of bound plus soluble peptide. Figure $2 B$ demonstrates that the addition of soluble VFDNFVLK significantly enhanced outgrowth compared with values obtained on bound VFDNFVLK alone (Fig. 2A), as reported previously (Meiners et al., 2001). Neurite outgrowth on bound plus excess soluble VFDNFVLK was reduced to control levels in the presence of $\beta 1$ antibody. Identical results were obtained using bound plus excess soluble fnD or D5 instead of VFDNFVLK (data not shown). This suggests that the substrate bound and soluble protein and peptide use the same receptor system.

Integrin activation requires receptor clustering as well as ligand binding (Tran et al., 2002). We therefore investigated the ability of VFDNFVLK to induce clustering of $\beta 1$ integrin subunits in growing neurites. Peptide was bound to PLL-coated coverslips, and cerebellar granule neurons were plated onto the coverslips and cultured for $24 \mathrm{hr}$. They were then reacted with an antibody against $\beta 1$ integrin chain. Neurons cultured on VFDNFVLK demonstrated punctate clusters of integrin immunoreactivity on the cell soma, neuritic processes, and growth cones compared with neurons cultured on PLL. On the other hand, neurons cultured on VSPNGSLK, which does not promote neurite outgrowth (Meiners et al., 2001), failed to demonstrate similar clusters despite a higher substrate coating efficiency for VSPNGSLK as opposed to VFDNFVLK $\left(10.2 \pm 1.4 \mathrm{pmol} / \mathrm{cm}^{2}\right.$ for VSPNGSLK vs $4.3 \pm 0.9 \mathrm{pmol} / \mathrm{cm}^{2}$ for VFDNFVLK) (Fig. 3). Similar negative results were obtained using a VASNAGLK peptide instead of VSPNGSLK, although the amino acid substitutions in VASNAGLK were more conservative than those in VSPNGSLK (data not shown). These results suggest that VFDNFVLK can activate a $\beta 1$ integrin neuronal receptor and that the residues FD and FV are required for receptor activation.

The $\alpha 7$ integrin subunit is implicated as the partner for $\boldsymbol{\beta} 1$

We investigated the possibility that the $\alpha 7$ integrin subunit acts as the partner for $\beta 1$ to mediate neurite outgrowth responses to VFDNFVLK (Bartsch et al., 1992; Pinkstaff et al., 1999). $\alpha 7$ is alternatively spliced in both the extracellular and cytoplasmic domains, giving rise to two extracellular (X1 and X2) and two predominant cytoplasmic (A and B) variants (Ziober et al., 2002). Our first step was to conduct a Western blot analysis to establish whether rat cerebellar granule neurons in fact express the $\alpha 7$ integrin and, if so, which splice variant(s). Using monoclonal O26 antibody (which cross-reacts with all splice variants of the $\alpha 7$ integrin subunit), a single polypeptide band was identified on blots with $M_{\mathrm{r}}$ of $-120,000$ (Fig. $4 A$ ). This polypeptide is of the correct size to represent the intact $\alpha 7$ chain (Gu et al., 1994). Identical results were obtained using polyclonal $\alpha 7 \mathrm{~B}$ antibody, whereas no bands were visible using polyclonal $\alpha 7 \mathrm{~A}$ antibody. Hence, cerebellar granule neurons express a variant of $\alpha 7$ integrin with the B cytoplasmic tail.

We next conducted an RT-PCR analysis of the expression of both cytoplasmic and extracellular $\alpha 7$ integrin variants in rat cerebellar granule neurons. Amplification with a sense primer specific for the X2 extracellular variant and an antisense primer common to both X1 and X2 variants yielded a PCR product of $200 \mathrm{bp}$ corresponding to the $\mathrm{X} 2$ isoform, whereas amplification with a sense primer specific for the $\mathrm{X} 1$ variant and the antisense 


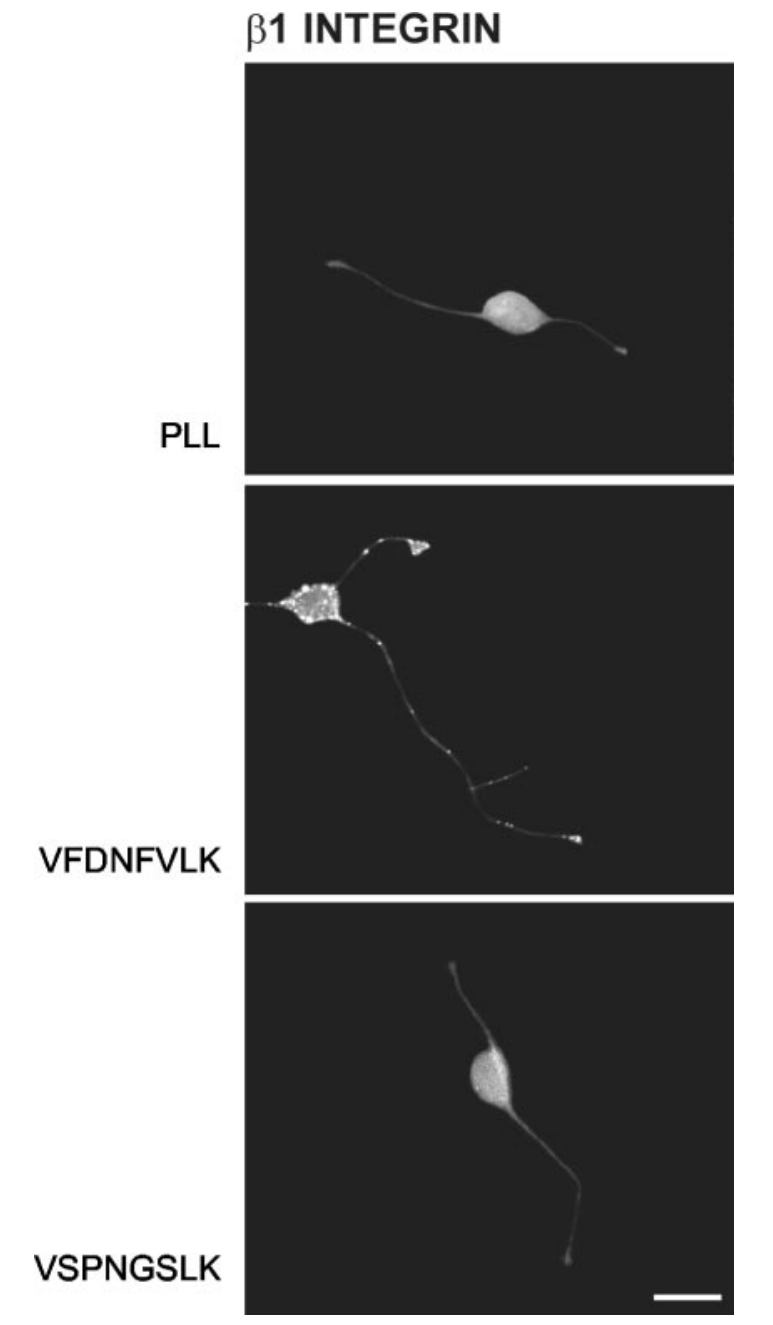

Figure 3. Neurons cultured on bound VFDNFVLK but not VSPNGSLK demonstrate clustering of immunoreactivity for $\beta 1$ integrin subunit. Immunocytochemistry was performed using a monoclonal hamster antibody against $\beta 1$ integrin chain, followed by a fluorescein-conjugated goat anti-hamster secondary antibody. VFDNFVLK but not VSPNGSLK induced clustering of neuronal $\beta 1$ integrin immunoreactivity. Scale bar, $10 \mu \mathrm{m}$.

primer common to both $\mathrm{X} 1$ and $\mathrm{X} 2$ yielded no PCR product corresponding to X1 (Fig. 4B). Furthermore, amplification with sense and antisense primers common to both the A and B cytoplasmic variants yielded a single PCR product of 370 bp corresponding to the $\mathrm{B}$ isoform; no $\mathrm{PCR}$ product corresponding to $\mathrm{A}$ (480 bp) was observed, in agreement with the Western blot results (Fig. 4A). Another amplification was performed using a second sense primer, this one specific to the A variant, in conjunction with the same antisense primer. Again, no PCR product corresponding to the A isoform was revealed. These results demonstrate that cerebellar granule neurons express the $\mathrm{X} 2 \mathrm{~B}$ variant of the $\alpha 7$ integrin subunit.

To explore whether the $\alpha 7$ integrin participates in the neuronal response to VFDNFVLK, we tested the O26 antibody for obstruction of neurite outgrowth promotion by the tenascin- $\mathrm{C}$ peptide. VFDNFVLK was bound to PLL-coated coverslips, as described in Materials and Methods. Rat cerebellar granule neurons were plated onto control and peptide-coated coverslips and cultured for $24 \mathrm{hr}$. O26 antibody $(0.5-100 \mu \mathrm{g} / \mathrm{ml})$ was added in some conditions $1 \mathrm{hr}$ after the neurons were plated and included during the remaining $23 \mathrm{hr}$ of the experiment. Process extension was then quantified. Figure 5 demonstrates that the $\mathrm{O} 26$ antibody

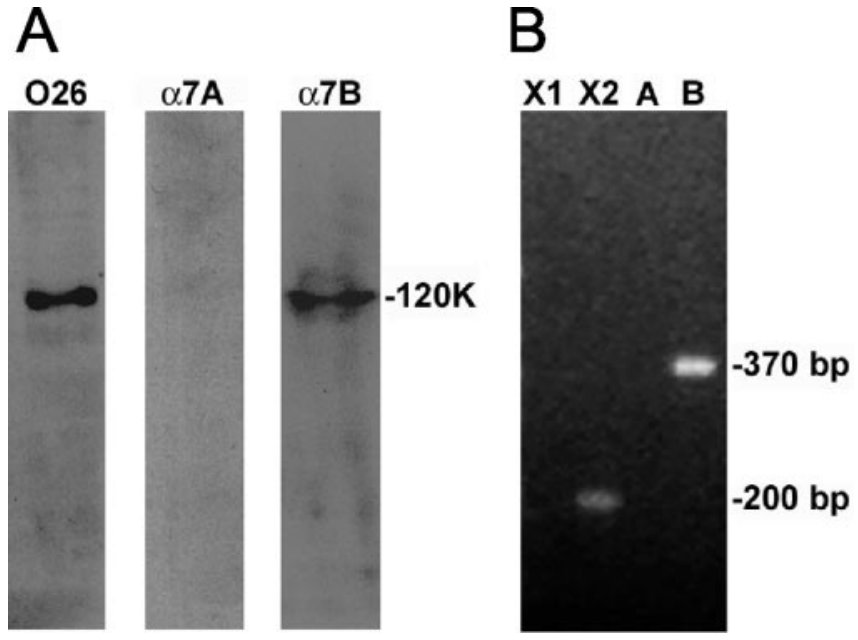

Figure 4. Cerebellar granule neurons express the X2B isoform of the $\alpha 7$ integrin subunit. $A$, Homogenate from P8 rat cerebellar granule neurons $(25 \mu \mathrm{g})$ was separated on $8 \%$ SDS-PAGE gels under nonreducing conditions and then transferred to nitrocellulose paper. Blots were probed with monoclonal 026 antibody, which cross-reacts with all splice variants of the $\alpha 7$ integrin chain, or polyclonal $\alpha 7 \mathrm{~A}$ or $\alpha 7 \mathrm{~B}$ antibodies, which cross-react with variants containing the A or B cytoplasmic tail. Immunoreactive bands were visualized using the enhanced chemiluminescence method. Blots probed with the 026 or $\alpha 7 \mathrm{~B}$ antibody demonstrated one predominant polypeptide band with $M_{\mathrm{r}}$ of 120,000 , whereas blots probed with the $\alpha 7 \mathrm{~A}$ antibody revealed no polypeptide band. $B$, RT-PCR was performed on total RNA prepared from P8 rat cerebellar granule neurons. Amplification was done using sense and antisense primers designed to amplify X1, X2, A, and B variants of the $\alpha 7$ integrin as described in Materials and Methods. The $200 \mathrm{bp}$ fragment corresponds to the $X 2$ extracellular variant, and the $370 \mathrm{bp}$ fragment corresponds to the B cytoplasmic variant. No products were obtained that corresponded to the X1 extracellular variant (220 bp) or the A cytoplasmic variant (480 bp).

did not alter neurite outgrowth on PLL at any concentration used but completely inhibited outgrowth promotion by VFDNFVLK at $10 \mu \mathrm{g} / \mathrm{ml}$. Inhibition was biphasic, with less inhibition observed at lower and higher antibody concentrations. This is reminiscent of the biphasic inhibition of myoblast migration on laminin-1 by the same antibody (Crawley et al., 1997) and may be attributable to direct receptor blockade at lower antibody concentrations coupled with some receptor cross-linking at higher antibody concentrations. The $\mathrm{O} 26$ antibody also blocked neurite outgrowth promotion by soluble VFDNFVLK (data not shown). Similar results were obtained using fnD or D5 instead of VFDNFVLK (data not shown). These data support the hypothesis that the $\alpha 7$ integrin chain acts in concert with $\beta 1$ to mediate neurite outgrowth responses to VFDNFVLK.

Specificity of the $\mathrm{O} 26$ antibody, as well as the potential involvement of other $\alpha$ integrin subunits in VFDNFVLK-mediated neurite promotion, was tested in outgrowth assays using function-blocking antibodies against rat $\alpha 1, \alpha 2$, and $\alpha 3$ integrin chains. Rat cerebellar granule neurons were plated onto control and peptide-coated coverslips, and antibodies $(0.5-100 \mu \mathrm{g} / \mathrm{ml})$ were added $1 \mathrm{hr}$ later. Neurons were cultured for an additional 23 hr. None of the antibodies altered the distributions of neurite length on PLL or VFDNFVLK at $10 \mu \mathrm{g} / \mathrm{ml}$ (Fig. $6 \mathrm{~A}$ ) or at any other concentration tested (data not shown). Lacking an equivalent antibody against rat $\alpha 6$ integrin, we also tested a functionblocking antibody against mouse $\alpha 6$ integrin chain in neurite outgrowth assays using mouse cerebellar granule neurons. This antibody also failed to alter neurite outgrowth on PLL or VFDNFVLK (Fig. 6B). Furthermore, none of the antibodies blocked neurite outgrowth by soluble VFDNFVLK (data not shown). Identical results were obtained in these experiments using fnD or 


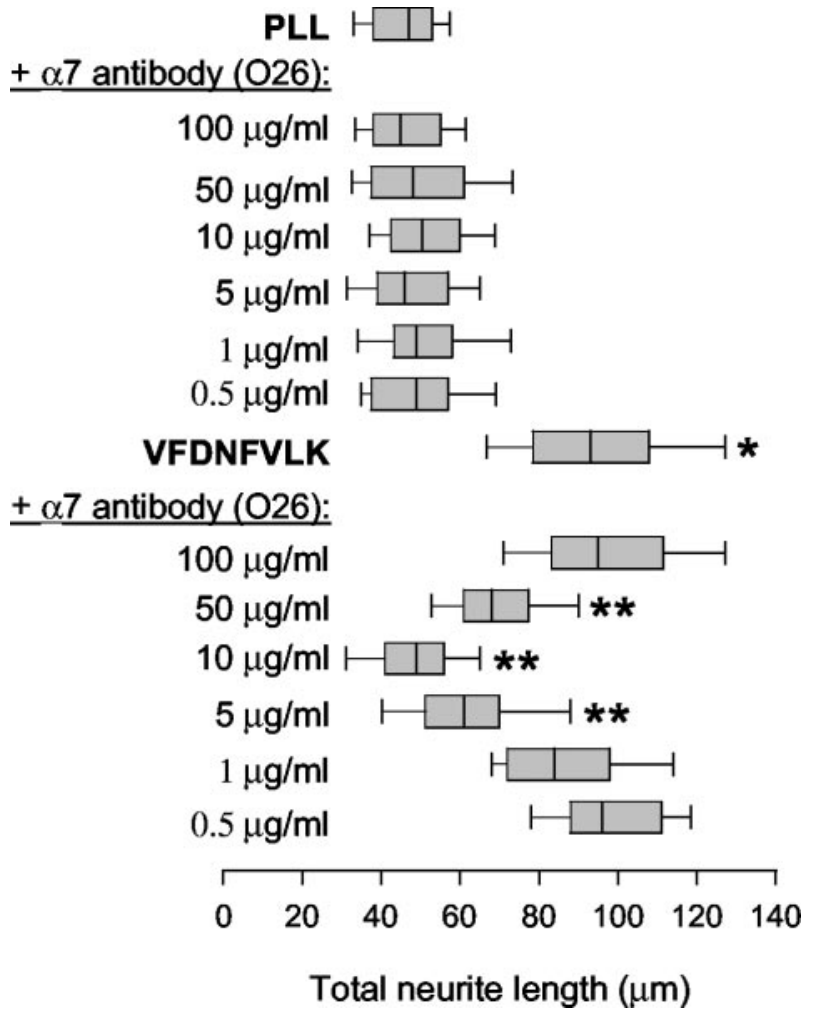

Figure 5. The $\alpha 7$ integrin subunit is implicated as the partner for $\beta 1$ in promotion of neurite outgrowth by VFDNFVLK. Rat cerebellar granule neurons were cultured for $24 \mathrm{hr}$ on PLL-coated glass coverslips in the presence of bound VFDNFVLK and function-blocking 026 antibody against $\alpha 7$ integrin subunit $(100,50,10,5,1$, or $0.5 \mu \mathrm{g} / \mathrm{ml})$. One representative experiment of three is shown. VFDNFVLK significantly enhanced outgrowth compared with the PLL control $\left({ }^{*} p<0.05\right.$; Kolmogorov-Smirnov test). The $\alpha 7$ integrin antibody did not alter neurite outgrowth on PLL at any concentration used. The antibody inhibited promotion of outgrowth by VFDNFVLK and demonstrated a biphasic concentration dependence. Outgrowth was significantly impaired at 50,10, and $5 \mu \mathrm{g} / \mathrm{ml} 026$ antibody ( ${ }^{* *} p<0.05$; Kolmogorov-Smirnov test), with maximal inhibition at $10 \mu \mathrm{g} / \mathrm{ml}$.

D5 instead of VFDNFVLK (data not shown). Therefore, the $\alpha 1$, $\alpha 2, \alpha 3$, and $\alpha 6$ integrin subunits do not appear to be involved in the facilitation of process extension by VFDNFVLK.

To investigate whether the $\alpha 7$ integrin interacts with native tenascin-C to promote neurite outgrowth, rat cerebellar granule neurons were plated onto PLL-coated coverslips containing bound large tenascin- $\mathrm{C}$ splice variant. The large tenascin- $\mathrm{C}$ splice variant used in this experiment contained the alternatively spliced FN-III repeats A1, A2, A3, A4, B, C, and D but not AD2 nor AD1 (see Fig. 1A). O26 antibody was added after $1 \mathrm{hr}$, and neurite lengths were measured after $23 \mathrm{hr}$. Large tenascin-C (substrate coating efficiency $5.9 \pm 0.9 \mathrm{pmol} / \mathrm{cm}^{2}$ ) supported considerable process extension compared with PLL (Fig. 7A), which was partially blocked by the $\mathrm{O} 26$ antibody. As with VFDNFVLK, inhibition of process extension on tenascin-C was biphasic (data not shown), with the maximal inhibition at $10 \mu \mathrm{g} / \mathrm{ml} \mathrm{O} 26$ antibody (illustrated in Fig. 7). No inhibition of neurite outgrowth was seen when small tenascin-C was used instead of large tenascin-C (data not shown). These results suggest that VFDNFVLK forms a functional $\alpha 7$ integrin binding site in the intact large tenascin- $\mathrm{C}$ protein and that other active sites and receptors also mediate outgrowth responses to tenascin-C. In addition, these results support our previous work indicating that the peptide sequence is active in tenascin-C (Meiners et al., 2001).

Neurite outgrowth experiments were also conducted for cer-
A

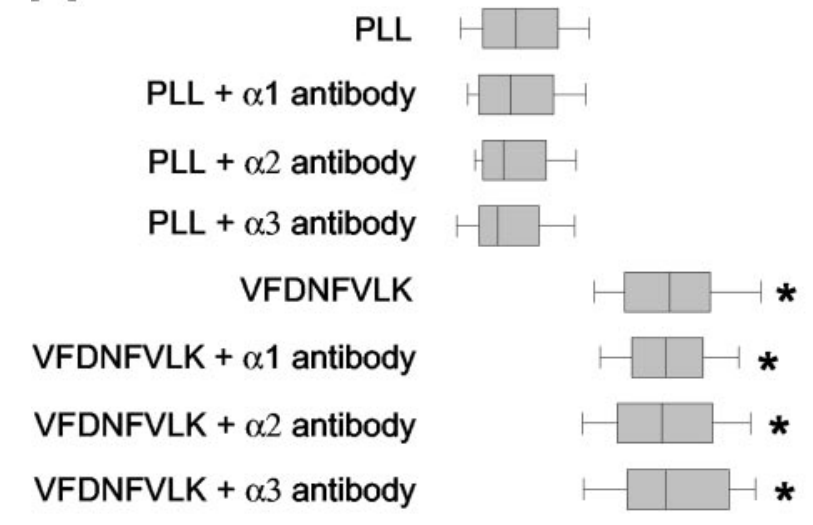

$\begin{array}{llllllll}0 & 20 & 40 & 60 & 80 & 100 & 120 & 140\end{array}$

Total neurite length $(\mu \mathrm{m})$

B

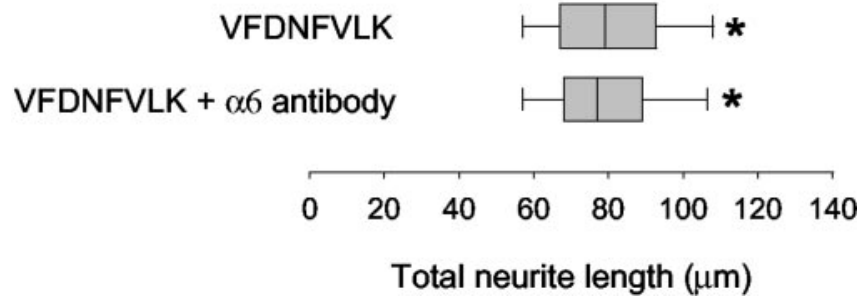

Figure 6. The $\alpha 1, \alpha 2, \alpha 3$, and $\alpha 6$ integrin subunits do not play a role in VFDNFVLKfacilitated neurite growth. Rat cerebellar granule neurons were cultured for $24 \mathrm{hr}$ on PLL-coated coverslips in the presence of bound VFDNFVLK and function-blocking antibodies against $\alpha 1$, $\alpha 2$, or $\alpha 3$ integrin subunits $(10 \mu \mathrm{g} / \mathrm{ml})(A)$, whereas mouse cerebellar granule neurons were cultured in the presence of bound VFDNFVLK and a function-blocking antibody against $\alpha 6$ integrin subunit $(10 \mu \mathrm{g} / \mathrm{ml})(B)$. One representative experiment of three is shown. VFDNFVLK significantly enhanced outgrowth compared with PLL ( ${ }^{*} p<0.05$; Kolmogorov-Smirnov test). None of the antibodies altered neurite outgrowth on PLL or VFDNFVLK.

ebellar granule neurons growing on a large tenascin- $\mathrm{C}$ substrate in the presence of the function-blocking antibody against $\beta 1$ integrin chain. The $\beta 1$ antibody completely blocked outgrowth promotion by tenascin-C (Fig. 7A), as reported previously by Varnum-Finney et al. (1995). Varnum-Finney et al. (1995) also demonstrated that a function-blocking antibody to $\alpha 8$ integrin partially blocked outgrowth promotion by tenascin- $\mathrm{C}$ from embryonic sensory and motor neurons and completely blocked outgrowth promotion by fn6-8, another tenascin- $\mathrm{C}$ region that supports neuronal process extension when substrate bound (Varnum-Finney et al., 1995; Meiners and Geller, 1997). Like embryonic sensory and motor neurons, rat cerebellar granule neurons express $\alpha 8$ integrin, as determined by RT-PCR analysis (data not shown). Therefore, large tenascin-C may promote neurite outgrowth via interactions with two neuronal $\beta 1$ integrins: $\alpha 7 \beta$ l and $\alpha 8 \beta 1$.

We then tested the $\mathrm{O} 26$ antibody for interference with outgrowth promotion by the extracellular matrix molecules laminin-1 and fibronectin. Laminin-1 and fibronectin $(20 \mu \mathrm{g} /$ 
A
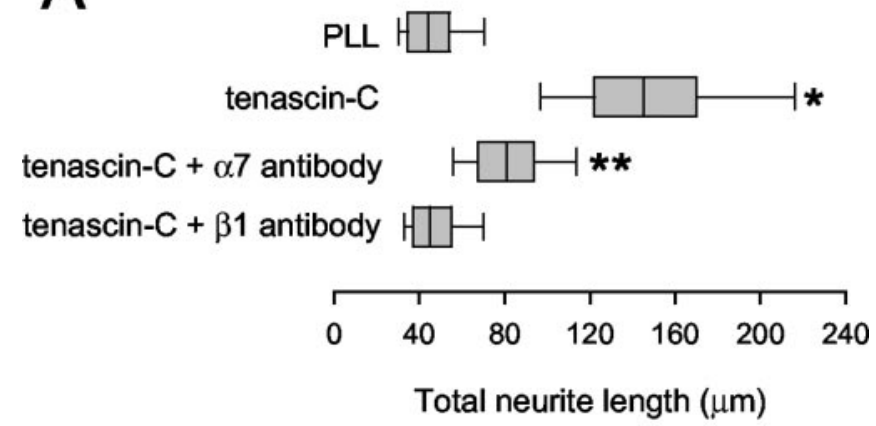

B

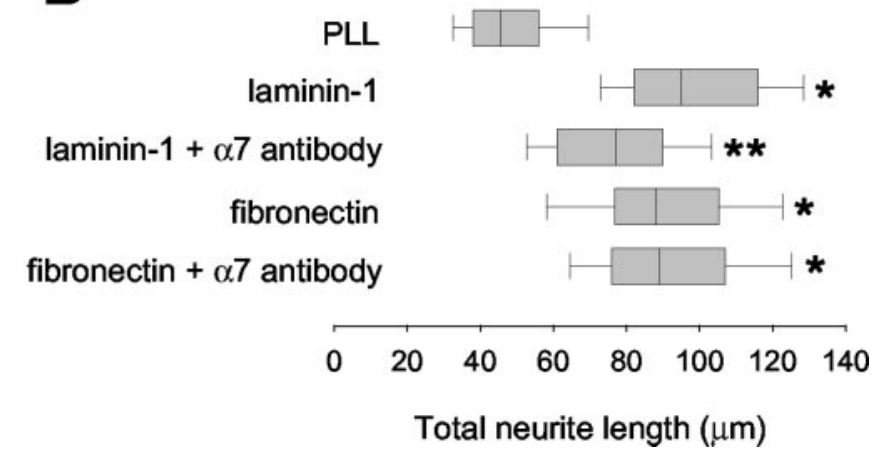

Figure 7. $\alpha 7$ integrin is involved in neurite outgrowth promotion by tenascin- $C$ and laminin- 1 but not by fibronectin. $A$, Rat cerebellar granule neurons were cultured for $24 \mathrm{hr}$ on PLL-coated coverslips in the presence of bound large tenascin-C and function-blocking antibody 026 against $\alpha 7$ integrin subunit or function blocking antibody against $\beta 1$ integrin subunit. 0 ne representative experiment of three is shown. Tenascin- $C$ significantly enhanced outgrowth compared with PLL ( ${ }^{*} p<0.05$; Kolmogorov-Smirnov test). The $\alpha 7$ antibody partially blocked outgrowth promotion by large tenascin- $C$; the reduction in outgrowth values was significant $\left({ }^{* *} p<0.05\right.$; Kolmogorov-Smirnov test). The $\beta 1$ integrin antibody completely blocked outgrowth promotion by large tenascin-C. $B$, Rat cerebellar granule neurons were cultured for $24 \mathrm{hr}$ on PLL-coated coverslips in the presence of bound laminin-1 or fibronectin and functionblocking 026 antibody against $\alpha 7$ integrin subunit. 0 ne representative experiment of three is shown. Laminin-1 and fibronectin significantly enhanced outgrowth compared with PLL ${ }^{*} p<$ 0.05 ; Kolmogorov-Smirnov test). The $\alpha 7$ antibody partially reduced neurite outgrowth on laminin-1; the reduction was significant ( ${ }^{* *} p<0.05$; Kolmogorov-Smirnov test). The antibody did not alter neurite outgrowth on fibronectin.

ml) were bound to PLL-coated coverslips. Rat cerebellar granule neurons were plated onto the coverslips, and $\mathrm{O} 26$ antibody was added $1 \mathrm{hr}$ later. After an additional $23 \mathrm{hr}$ in culture, the extent of neurite outgrowth was assessed. Laminin-1 and fibronectin (with substrate coating efficiencies of $8.2 \pm 1.4$ and $6.5 \pm 0.9 \mathrm{pmol} /$ $\mathrm{cm}^{2}$, respectively) both facilitated process extension compared with PLL (Fig. 7B). The O26 antibody had no effect on neurite outgrowth on fibronectin but partially blocked neurite outgrowth promotion by laminin-1. This suggests that the $\alpha 7$ integrin does not mediate neurite outgrowth responses to fibronectin but is perhaps one of several neuronal receptors mediating outgrowth responses to laminin-1.

\section{The $\alpha 7 \beta 1$ integrin binds to VFDNFVLK-containing peptides in an FD-FV-dependent manner}

We next investigated whether the neurite outgrowth-promoting motif in tenascin- $\mathrm{C}$ can biochemically associate with $\alpha 7 \beta 1$ integrin derived from rat cerebellar granule neurons. To do this, ligand binding assays were performed using affinity chromatography with D5 and modified D5 peptides conjugated to Sepha- rose beads. As mentioned in Materials and Methods, D5 peptide was used instead of VFDNFVLK because it is more hydrophilic and readily soluble, allowing for the conjugation of a larger amount of protein. The modified peptides included D5 mutant 1 (FD and FV substituted with SP and GS), D5 mutant 2 (FD substituted with SP), and D5 mutant 3 (FV substituted with GS). These peptides, based on those used previously to identify critical residues in fnD and VFDNFVLK for neurite outgrowth promotion (Meiners et al., 2001), fail to facilitate neuronal process extension (data not shown).

Neuronal proteins were extracted as described in Materials and Methods using $n$-octyl- $\beta$-D-glucopyranoside and Triton X-100. Wild-type D5- and D5 mutant-conjugated Sepharose beads were then incubated with the neuronal extract to allow any integrin binding to occur, washed, and eluted with EDTA. The presence of $\alpha 7$ and $\beta 1$ integrin subunits in the eluates was assessed by Western blotting with $\mathrm{O} 26$ antibody and polyclonal $\beta 1$ integrin antibody. Both integrin subunits were detected on Western blots for material eluted from wild-type D5-conjugated beads but not for material eluted from D5 mutant 1-conjugated beads (Fig. $8 A$ ) or from D5 mutant 2 or D5 mutant 3-conjugated beads (data not shown). No $\alpha 7$ or $\beta 1$ polypeptide bands were observed when control Sepharose was substituted for D5-conjugated Sepharose (data not shown).

Silver-stained gels of proteins eluted from wild-type D5 peptide (Fig. $8 \mathrm{~B}$ ) revealed predominant overlapping polypeptide bands with $M_{\mathrm{r}}$ of 120,000 and 116,000 , corresponding to the relative mobilities of the bands recognized by the $\mathrm{O} 26$ and $\beta 1$ integrin antibodies. The appearance of these overlapping bands is typical and has been reported previously (Crawley et al., 1997). The bands were not detected for proteins eluted from D5 mutant 1 peptide (Fig. $8 \mathrm{~B}$ ), D5 mutant 2 or D5 mutant 3 peptide (data not shown), or control Sepharose (data not shown). The Western blot and silver stain data indicate that neuronal $\alpha 7 \beta 1$ integrin binds specifically to the D5 peptide and that FD and FV are critical for the association, just as they are both required for neurite outgrowth promotion by fnD, D5, and VFDNFVLK (Meiners et al., 2001). The same conclusion is supported by the fact that incubation of neuronal proteins with wild-type D5 peptide followed by immunoprecipitation with $\beta 1$ integrin antibody resulted in the presence of $\beta 1$ integrin subunit, $\alpha 7$ integrin subunit, and peptide in the immunoprecipitate, whereas substitution of D5 mutant peptide for wild-type D5 peptide resulted in no peptide in the immunoprecipitate (data not shown). In other affinity chromatography experiments, integrin binding was also detected to $\mathrm{fnD}$ and large tenascin- $\mathrm{C}$ (data not shown). This supports the antibody blocking results of Figure 7 and indicates that the $\alpha 7 \beta 1$ binding site is not cryptic in native tenascin-C.

\section{Discussion}

The fnD repeat of tenascin-C facilitates neurite extension in culture by itself and as part of intact tenascin- $\mathrm{C}$ (Meiners et al., 2001). Tenascin- $C$ splice variants containing this domain are preferentially expressed during periods of increased axonal growth in the developing CNS (Joester and Faissner, 1999), suggesting that $\mathrm{fnD}$ also stimulates neuronal growth in vivo. Previous work showed that the sequence VFDNFVLK derived from human tenascin- $\mathrm{C}$ was necessary and sufficient for neurite outgrowth promotion by fnD (Meiners et al., 2001). This study shows that function-blocking antibodies against $\alpha 7$ and $\beta 1$ integrin subunits eliminate the neuronal response to VFDNFVLK and that $\alpha 7 \beta 1$ binds to tenascin-C peptides containing VFDNFVLK. This is the first demonstration that $\alpha 7 \beta 1$ integrin medi- 


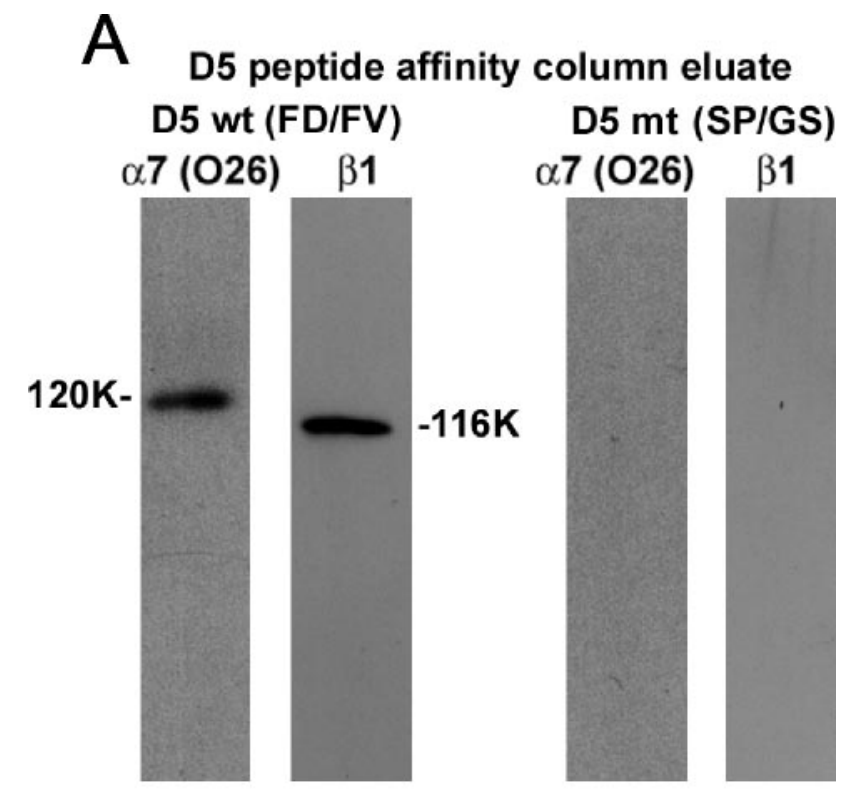

B

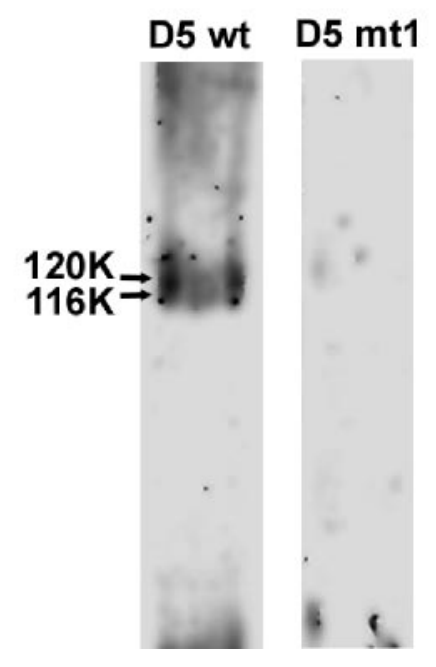

Figure 8. Neuronal $\alpha 7 \beta 1$ integrin binds to D5 peptide in an FD-FV-dependent manner. P8 cerebellar granule neuronal extracts were incubated with Sepharose beads conjugated with either wild-type D5 peptide (D5 wt) or D5 mutant 1 peptide with alterations in both FD and FV (D5 mt). A, Proteins eluted with EDTA from wild-type or mutant D5 peptide were separated on $8 \%$ SDS-PAGE gels under nonreducing conditions and transferred to nitrocellulose paper. Blots were probed with monoclonal 026 antibody against $\alpha 7$ integrin chain or polyclonal antibody against $\beta 1$ integrin chain. Immunoreactive bands were visualized using the enhanced chemiluminescence method. Blots of proteins eluted with EDTA from D5 wt peptide revealed polypeptide bands with $M_{\mathrm{r}}$ of 120,000 and 116,000 , respectively, for the 026 and $\beta 1$ integrin antibodies. Blots of proteins eluted with EDTA from D5 $\mathrm{mt}$ peptide revealed no polypeptide bands. $B$, Silver-stained gels revealed overlapping polypeptide bands with $M_{\mathrm{r}}$ of 120,000 and 116,000 for proteins eluted with EDTA from D5 wt peptide but not D5 $\mathrm{mt} 1$ peptide.

ates a response to tenascin- $\mathrm{C}$ and the first functional data on the role of $\alpha 7 \beta 1$ in CNS neurons.

Neurite outgrowth promotion from cerebellar granule neurons by native tenascin-C was partially but not wholly blocked by the $\alpha 7$ antibody (Fig. 7A), suggesting that $\alpha 7 \beta 1$ forms a functional interaction with tenascin-C as well as VFDNFVLK. This also suggests that tenascin-C sequences outside of VFDNFVLK promote neurite outgrowth via other receptors. fn6-8, as noted above, facilitates process extension via $\alpha 8 \beta 1$ integrin (VarnumFinney et al., 1995), and fnB-D promotes outgrowth via F3/con- tactin but only when $\mathrm{fnB}$ and $\mathrm{fnD}$ are not interrupted by $\mathrm{fnC}$ (Rigato et al., 2002). Accordingly, it is possible that amino acids in $\mathrm{fnB}$ and $\mathrm{fnD}$ form an active site for neurite extension and F3/ contactin binding only when the two FN-III repeats are adjacent to one another, a spatial coordination that cannot occur in the presence of fnC. The RGD site in fn 3 binds to $\alpha \mathrm{v} \beta 3$ integrin (Joshi et al., 1993; Sriramarao et al., 1993), but fn3 does not promote outgrowth from CNS neurons (Phillips et al., 1995; Gotz et al., 1996; Meiners and Geller, 1997). Together with the $\beta 1$ integrin blocking data (Fig. 7A), it seems likely that the fnCcontaining tenascin-C splice variant used in this study promotes neurite outgrowth via two sites-receptors: fn $6-8$ and $\alpha 8 \beta 1$, and VFDNFVLK and $\alpha 7 \beta 1$.

Similar to the results with tenascin-C, laminin-1-facilitated cerebellar granule neuron process extension was partially blocked by the $\alpha 7$ antibody. Because $\beta 1$ is the only known integrin subunit binding partner for $\alpha 7$ (Hynes, 1992), this indicates that $\alpha 7 \beta 1$ encourages cerebellar granule neurites to grow longer on laminin-1 as well as tenascin-C. The partial block observed was likely attributable to the fact that several integrins, not just $\alpha 7 \beta 1$, act together to mediate outgrowth responses to laminin-1. For example, $\alpha 3 \beta 1$ and $\alpha 6 \beta 1$, which are both expressed in cerebellum (Pinkstaff et al., 1999), recognize RGD- and IKLLI-containing neurite-promoting sequences, respectively, in laminin-1 (Tomaselli et al., 1990; Tashiro et al., 1991). The amino acid sequence in laminin-1 that binds to $\alpha 7 \beta 1$ remains to be determined, but laminin-1 does not contain a sequence homologous to VFDNFVLK. Furthermore, a VFDNFVLK-containing peptide did not elute $\alpha 7 \beta 1$ integrin bound to laminin-1 (data not shown).

The $\alpha 7 \beta 1$ integrin has also been shown to bind to the RGD motif of fibronectin (Gu et al., 1994). Fibronectin, like tenascin-C and laminin-1, promoted neurite outgrowth from cerebellar granule neurons in this study. However, the $\alpha 7$ antibody did not block outgrowth responses to fibronectin. This implies that $\alpha 7 \beta 1$ and RGD do not interact to facilitate cerebellar granule neuronal process extension on fibronectin, just as they do not appear to interact to mediate myoblast adhesion or migration on fibronectin (Crawley et al., 1997). Like myoblast interactions with fibronectin, neurite outgrowth may rely instead on another fibronectin-binding integrin, such $\alpha 5 \beta 1$.

We showed previously that VFDNFVLK overcomes chondroitin sulfate proteoglycan (CSPG)-mediated impairment of neurite outgrowth (Meiners et al., 2001). CSPGs are upregulated on glial scars (McKeon et al., 1991), and the preponderance of evidence indicates that they are inhibitory to axonal regrowth after CNS injury (Gates et al., 1996; Zuo et al., 1998). Hence, VFDNFVLK may have a potential role in regenerative strategies. Function-blocking $\alpha 7$ and $\beta 1$ antibodies eliminated the ability of VFDNFVLK to increase outgrowth on CSPGs (Meiners, unpublished data), suggesting that neuronal receptor activation, and not stearic hindrance of CSPGs by the peptide, was responsible for the actions of VFDNFVLK. It thus appears that VFDNFVLK increases neurite length in the absence and presence of CSPGs via interactions with $\alpha 7 \beta 1$.

Neurons in the developing CNS are capable of substantial neurite regeneration (Bandtlow and Loschinger, 1997), whereas neurons in the adult CNS normally do not regenerate (Plunet et al., 2002). That VFDNFVLK increases neurite outgrowth from early postnatal neurons via interactions with an integrin has important implications for its utility in therapeutic strategies. We and others (Davies et al., 1997; Meiners et al., 1999; Chen et al., 2000) have suggested that an inhibitory environment with a paucity of growth-promoting molecules, matrix derived or other- 
wise, contributes to failed regeneration in the adult CNS. However, a reduced number of receptors for growth-promoting molecules on adult versus young neurons may also play a major role. In support of this idea, adult dorsal root ganglion neurons, which do not regenerate their central processes, demonstrated low integrin expression and poor process extension on laminin-1 and fibronectin compared with early postnatal neurons. Increasing the expression of $\alpha 1$ or $\alpha 5$ integrins in adult neurons by gene transfer methods resulted in greatly enhanced neurite outgrowth on laminin-1 and fibronectin, respectively (Condic, 2001). Hence, maximal neurite regrowth in the injured adult CNS will probably involve a strategy to increase expression of integrins and other key receptors in damaged neurons, as well as provision of a regeneration mixture of growth-promoting molecules such as VFDNFVLK.

Like embryonic CNS neurons, adult PNS neurons are capable of extensive neurite regeneration (Plunet et al., 2002). Here again, successful regeneration is closely correlated with the induction of neuronal integrins. For example, embryonic peripheral neurons, and perhaps adult peripheral neurons as well, can adapt to CSPG inhibition of neurite outgrowth by increasing their expression of $\alpha 3 \beta 1$ and $\alpha 6 \beta 1$ integrins (Condic et al., 1999). Furthermore, elevated expression of $\alpha 4$ (Vogelezang et al., 2001) and $\alpha 7 \beta 1$ (Werner et al., 2000) integrins in adult wild-type mice has been connected to the successful regrowth of damaged peripheral neuronal processes. $\alpha 7$ knock-out mice demonstrated impaired axonal regrowth and delayed target reinnervation in the facial nerve (Werner et al., 2000), suggesting that $\alpha 7 \beta 1$ is absolutely critical for regeneration in the PNS. Significantly, $\alpha 7 \beta 1$ was not increased after central nerve injury, leaving open the question of whether low expression of this and other integrins is a limiting factor in CNS regeneration.

Laminin-1 was suggested to be the neurite outgrowthpromoting ligand for $\alpha 7 \beta 1$ in the PNS (Werner et al., 2000). However, tenascin-C, like laminin-1, is upregulated after PNS injury and is appropriately localized to provide growthpromoting cues to regenerating neurites (Kuecherer-Ehret et al., 1990; Martini et al., 1990; Yip et al., 1995; Zhang et al., 1995). Moreover, work in frog (Mege et al., 1992) and mouse (Langenfeld-Oster et al., 1994) using function-blocking antibodies to tenascin- $\mathrm{C}$ to interrupt its function in vivo showed that, as in the $\alpha 7$ knock-out mouse, target reinnervation was greatly delayed or inhibited. In light of our current results, it seems likely that tenascin- $\mathrm{C}$ as well as laminin- 1 could be a peripheral ligand for $\alpha 7 \beta 1$ integrin.

On the other hand, closer examination suggests that tenascin- $\mathrm{C}$ may play more of a guidance role as opposed to an outgrowth-promoting role after PNS trauma. For example, axonal regrowth did in fact occur in the frog study (Mege et al., 1992) and the tenascin-C knock-out mouse (Cifuentes-Diaz et al., 2002), but the paths that the regrowing nerves traveled were altered compared with controls. We showed that tenascin-C provides independent outgrowth-promoting and guidance cues to cerebellar granule neurites in vitro (Meiners et al., 1999). Therefore, these studies indicate that other molecules such as laminin-1 may compensate for some outgrowth-promoting functions normally provided by tenascin- $\mathrm{C}$ in vivo but not its ability to guide peripheral neurites by confining them to specific paths. Although we have not as of yet determined a role for $\beta 1$ integrins in tenascin-C-mediated guidance of cerebellar granule neuronal processes, potential involvement of the $\alpha 7 \beta 1$ in tenascin-Cmediated guidance of PNS axons remains to be investigated.

In conclusion, we showed that enhancement of neuronal pro- cess extension by tenascin- $\mathrm{C}$ and the tenascin-C-derived sequence VFDNFVLK is eliminated by function-blocking antibodies against both $\alpha 7$ and $\beta 1$ integrin subunits. Alteration of the conserved residues FD and FV destroys the ability of $\alpha 7 \beta 1$ to associate with the peptide, indicating that these amino acids are important for receptor binding. We suggested previously that VFDNFVLK might find applicability as a reagent to promote neurite growth in otherwise inhibitory environments (Meiners et al., 2001). Given that $\alpha 7 \beta 1$ is increased in neurons after PNS but not CNS injury (Werner et al., 2000), our results suggest that manipulating the expression of this receptor in damaged CNS neurons might improve their ability to regenerate in response to reagents such as VFDNFVLK.

\section{References}

Aukhil I, Joshi P, Yan Y, Erickson HP (1993) Cell- and heparin-binding domains of the hexabrachion arm identified by tenascin expression proteins. J Biol Chem 268:2542-2553.

Bandtlow CE, Loschinger J (1997) Developmental changes in neuronal responsiveness to the CNS myelin-associated neurite growth inhibitor NI35/250. Eur J Neurosci 9:2743-2752.

Bartsch S, Bartsch U, Dorries U, Faissner A, Weller A, Ekblom P, Schachner M (1992) Expression of tenascin in the developing and adult cerebellar cortex. J Neurosci 12:736-749.

Bronner-Fraser M (1988) Distribution and function of tenascin during cranial neural crest development in the chick. J Neurosci Res 21:135-147.

Burkin DJ, Gu M, Hodges BL, Campanelli JT, Kaufman SJ (1998) A functional role for specific spliced variants of the $\alpha 7 \beta 1$ integrin in acetylcholine receptor clustering. J Cell Biol 143:1067-1075.

Chen MS, Huber AB, van der Haar ME, Frank M, Schnell L, Spillman AA, Christ F, Schwab ME (2000) Nogo-A is a myelin-associated neurite outgrowth inhibitor and an antigen for monoclonal antibody IN-1. Nature 403:434-439.

Chiquet M, Fambrough DM (1984) Chick myotendinous antigen. I. A monoclonal antibody as a marker for tendon and muscle morphogenesis. J Cell Biol 98:1926-1936.

Cifuentes-Diaz C, Faille L, Goudou D, Schachner M, Rieger F, Angaut-Petit D (2002) Abnormal reinnervation of skeletal muscle in a tenascin-Cdeficient mouse. J Neurosci Res 67:93-99.

Condic ML (2001) Adult neuronal regeneration induced by transgenic integrin expression. J Neurosci 21:4782-4788.

Condic ML, Snow DM, Letourneau PC (1999) Embryonic neurons adapt to the inhibitory proteoglycan aggrecan by increasing integrin expression. J Neurosci 19:10036-10043.

Crawley S, Farrell EM, Wang W, Gu M, Huang HY, Huynh V, Hodges BL, Cooper DN, Kaufman SJ (1997) The alpha7betal integrin mediates adhesion and migration of skeletal myoblasts on laminin. Exp Cell Res 235:274-286

Crossin KL, Hoffman S, Tan SS, Edelman GM (1989) Cytotactin and its proteoglycan ligand mark structural and functional boundaries in somatosensory cortex of the early postnatal mouse. Dev Biol 136:381-392.

Davies SJ, Fitch MT, Memberg SP, Hall AK, Raisman G, Silver J (1997) Regeneration of adult axons in white matter tracts of the central nervous system. Nature 390:680-683.

Gates MA, Fillmore H, Steindler DA (1996) Chondroitin sulfate proteoglycan and tenascin in the wounded adult mouse neostriatum in vitro: dopamine neuron attachment and process outgrowth. J Neurosci 16:8005-8018.

Gotz B, Scholze A, Clement A, Joester A, Schutte K, Wigger F, Frank R, Spiess E, Ekblom P, Faissner A (1996) Tenascin-C contains distinct adhesive, anti-adhesive, and neurite outgrowth promoting sites for neurons. J Cell Biol 132:681-699.

Gu M, Wang W, Song WK, Cooper DN, Kaufman SJ (1994) Selective modulation of the interaction of $\alpha 7 \beta 1$ integrin with fibronectin and laminin by L-14 lectin during skeletal muscle differentiation. J Cell Sci 107:175-181.

Huang XZ, Wu JF, Ferrando R, Lee JH, Wang YL, Farese RVJr, Sheppard D (2000) Fatal bilateral chylothorax in mice lacking the integrin alpha9beta1. Mol Cell Biol 20:5208-5215.

Hynes R (1992) Integrins, versatility, modulation, and signaling in cell adhesion. Cell 11-25. 
Joester A, Faissner A (1999) Evidence for combinatorial variability of tenascin-C isoforms and developmental regulation in the mouse central nervous system. J Biol Chem 274:17144-17151.

Joshi P, Chung CY, Aukhil I, Erickson HP (1993) Endothelial cells adhere to the RGD domain and the fibrinogen-like terminal knob of tenascin. J Cell Sci 106:389-400.

Kramer RH, Vu MP, Chen Y-F, Ramos DM, Timpl R, Waleh N (1991) Laminin-binding integrin $\alpha 7 \beta 1$ : functional characterization and expression in normal and malignant melanocytes. Cell Regul 2:805-817.

Kuecherer-Ehret A, Graeber MB, Edgar D, Thoenen H, Kreutzberg GW (1990) Immunoelectron microscopic localization of laminin in normal and regenerating mouse sciatic nerve. J Neurocytol 19:101-109.

Laemmli UK (1970) Cleavage of structural proteins during the assembly of the head of bacteriophage T4. Nature 227:680-685.

Langenfeld-Oster B, Faissner A, Irintchev A, Wernig A (1994) Polyclonal antibodies against NCAM and tenascin delay endplate reinnervation. J Neurocytol 23:591-604.

Leahy DJ, Hendrickson WA, Aukhil I, Erickson HP (1992) Structure of a fibronectin type III domain from tenascin-C by MAD analysis of the selenomethionyl protein. Science 258:987-991.

Martini R, Schachner M, Faissner A (1990) Enhanced expression of the extracellular matrix molecule J1/tenascin in the regenerating adult mouse sciatic nerve. J Neurocytol 19:601-616.

McKeon RJ, Schreiber RC, Rudge JS, Silver J (1991) Reduction of neurite outgrowth in a model of glial scarring following CNS injury is correlated with the expression of inhibitory molecules on reactive astrocytes. J Neurosci 11:3398-3411.

Mege RM, Nicolet M, Pincon-Raymond M, Murawsky M, Rieger F (1992) Cytotactin is involved in synaptogenesis during regeneration of the frog neuromuscular system. Dev Biol 149:381-394.

Meiners S, Geller HM (1997) Long and short splice variants of human tenascin differentially regulate neurite outgrowth. Mol Cell Neurosci 10:100-116.

Meiners S, Mercado ML, Kamal MS, Geller HM (1999) Tenascin-C contains domains that independently regulate neurite outgrowth and neurite guidance. J Neurosci 19:8443-8453.

Meiners S, Nur-e-Kamal MSA, Mercado MLT (2001) Identification of a neurite outgrowth promoting motif within the alternatively spliced region of tenascin-C. J Neurosci 21:7215-7225.

Petroski RE, Geller HM (1994) Selective labeling of embryonic neurons cultured on astrocyte monolayers with 5(6)-carboxyfluorescein diacetate (CFDA). J Neurosci Methods 52:23-32.

Phillips GR, Edelman GM, Crossin KL (1995) Separate cell binding sites within cytotactin/tenascin differentially promote neurite outgrowth. Cell Adhes Commun 3:257-271.

Pinkstaff JK, Detterich J, Lynch G, Gall C (1999) Integrin subunit gene expression is regionally differentiated in adult brain. J Neurosci 19:1541-1556.

Plunet W, Kwon BK, Tetzlaff W (2002) Promoting axonal regeneration in the central nervous system by enhancing the cell body response to axotomy. J Neurosci Res 68:1-6.

Rigato F, Garwood J, Calco V, Heck N, Faivre-Sarrailh C, Faissner A (2002) Tenascin-C promotes neurite outgrowth of embryonic hippocampal neurons through the alternatively spliced fibronectin type III BD domains via activation of the cell adhesion molecule F3/contactin. J Neurosci 22:6596-6609.

Ruoslahti E (1996) RGD and other recognition sequences for integrins. Annu Rev Cell Dev Biol 12:697-715.

Sriramarao P, Mendler M, Bourdon MA (1993) Endothelial cell attachment and spreading on human tenascin is mediated by $\alpha 2 \beta 1$ and $\alpha v \beta 3$ integrins. J Cell Sci 105:1001-1012.

Tashiro K, Sephel GC, Greatorex D, Sasaki M, Shirashi N, Martin GR, Kleinman HK, Yamada Y (1991) The RGD containing site of mouse laminin A chain is active for cell attachment, spreading, migration and neurite outgrowth. J Cell Physiol 146:451-459.

Tomaselli KJ, Hall DE, Flier LA, Gehlsen KR, Turner DC, Carbonetto S, Reichardt LF (1990) A neuronal cell line (PC12) expresses two $\beta 1$-class integrins- $\alpha 1 \beta 1$ and $\alpha 3 \beta 1$-that recognize different neurite outgrowthpromoting domains in laminin. Neuron 5:651-662.

Towbin H, Staehelin T, Gordon J (1979) Electrophoretic transfer of proteins from polyacrylamide gels to nitrocellulose sheets: procedures and some applications. Proc Natl Acad Sci USA 76:4350-4354.

Tran H, Pankov R, Tran SD, Hampton B, Burgess WH, Yamada KM (2002) Integrin clustering induces kinectin accumulation. J Cell Sci 115:2031-2040.

Tucker RP (1993) The in situ localization of tenascin splice variants and thrombospondin 2 mRNA in the avian embryo. Development 117:347-358

Vachon PH, Xu H, Liu L, Loechel F, Hayashi Y, Arahata K, Reed JC, Wewer UM, Engvall E (1997) Integrins in muscle function and survival. J Clin Invest 100:1870-1881.

Varnum-Finney B, Venstrom K, Muller U, Kypta R, Backus C, Chiquet M, Reichardt LF (1995) The integrin receptor alpha 8 beta 1 mediates interactions of embryonic chick motor and sensory neurons with tenascin-C. Neuron 14:1213-1222.

Vogelezang MG, Liu Z, Relvas JB, Raivich G, Scherer SS, ffrench-Constant C (2001) $\alpha 4$ integrin is expressed during peripheral nerve regeneration and enhances neurite outgrowth. J Neurosci 21:6732-6744.

Werner A, Willem M, Jones LL, Kreutzberg GW, Mayer U, Raivich G (2000) Impaired axonal regeneration in $\alpha 7$ integrin-deficient mice. J Neurosci 20:1822-1830.

Yip JW, Yip YP, Capriotti C (1995) The expression, origin and function of tenascin during peripheral nerve formation in the chick. Brain Res Dev Brain Res 86:297-310.

Yokosaki Y, Matsuura N, Higashiyami S, Murakami I, Obara M, Yamakido M, Shigeto N, Chen J, Sheppard D (1998) Identification of the ligand binding site for the integrin $\alpha 9 \beta 1$ in the third fibronectin type III repeat of tenascin-C. J Biol Chem 273:11423-11428.

Zhang Y, Campbell G, Anderson PN, Martini R, Schachner M, Lieberman AR (1995) Molecular basis of interactions between regenerating adult rat thalamic axons and Schwann cells in peripheral nerve grafts. II. Tenascin-C. J Comp Neurol 1995:210-224.

Ziober BL, Vu MP, Waleh N, Crawford J, Lin C-S, Kramer RH (2002) Alternative extracellular and cytoplasmic domains of the integrin $\alpha 7$ subunit are differentially expressed during development. J Biol Chem 268:26773-26783.

Zuo J, Neubauer D, Dyess K, Ferguson TA, Muir D (1998) Degradation of chondroitin sulfate proteoglycan enhances the neurite-promoting potential of spinal cord tissue. Exp Neurol 154:654-662. 